\title{
Characterization of the clientele and evaluation of health care service of the person with elimination stoma
}

\section{Caracterização da clientela e avaliação de serviço de atenção à saúde da pessoa com estomia de eliminação}

\section{Caracterización de la clientela y evaluación de servicio de atención a la salud de la persona con estomía de eliminación}

Jaqueline de Paula Chaves Freitas' ${ }^{1}$ Eline Lima Borges ${ }^{1}$, Emerson Cotta Bodevan²

ORCID IDS

Freitas JPC (D) https://orcid.org/0000-0002-2688-2676

Borges EL (iD https://orcid.org/0000-0002-0623-5308

Bodevan EC (D) https://orcid.org/0000-0001-7471-9956
HOW TO CITE

Freitas JPC; Borges EL; Bodevan EC. Characterization of the clientele and evaluation of health care service of the person with elimination stoma. ESTIMA, Braz. J. Enterostomal Ther., 16: e0918. doi: 10.30886/ estima.v16.402.

\begin{abstract}
Objectives: To characterize clientele with elimination stoma and to analyze the degree of implementation of the Health Care Policy of Ostomized Person in Diamantina/MG. Method: Descriptive and cross-sectional study. The sample consisted of 107 people with elimination stoma registered in the period from October 2013 to August 2015. The study involved two stages in which the profile of the clientele was characterized and the entire structure of the Health Care Policy of Ostomized Person was analyzed according to validated questionnaires. Results: It was found that most of the participants were men, elderly, with a recent stoma, white colour, married, employed by a farmer and retired, schooling from 1 to 5 years and salary range of 1 to 2 minimum wages. The precursor disease of the stomas was colorectal cancer. The Health Care Policy of Ostomized Person in Diamantina can be characterized as level II, with satisfactory, but not full implantation. Conclusion: It is expected that these discoveries may support guidelines for multidisciplinary orientation and public policies.
\end{abstract}

DESCRIPTORS: Stomatherapy; Evaluation of health care service; Self-care

\footnotetext{
'Universidade Federal de Minas Gerais - Escola de Enfermagem - Programa de Pós-Graduação em Enfermagem, Belo Horizonte/MG - Brazil. 2Universidade Federal dos Vales do Jequitinhonha e Mucuri - Departamento de Matemática e Estatística - Diamantina/MG - Brazil. Correspondence author: Jaqueline de Paula Chaves Freitas | Rua Pedro de Alcântara, 400 B - Jardim Imperial | ZIP Code: $39100-000$ Diamantina/MG - Brazil | E-mail: jaquelinechavesjp@yahoo.com.br

Received: Oct 032016 | Accepted: May 122017
} 


\section{RESUMO}

Objetivos: Caracterizar a clientela com estomia de eliminação e analisar o grau de implantação da Política de Atenção à Saúde da Pessoa Ostomizada de Diamantina/MG. Método: Estudo descritivo e transversal. A amostra foi composta por 107 pessoas com estomia de eliminação cadastradas no período de outubro de 2013 a agosto de 2015. O estudo envolveu duas etapas nas quais se caracterizou o perfil da clientela e analisou toda a estrutura do Serviço de Atenção à Saúde da Pessoa Ostomizada de acordo com questionários validados. Resultados: Constatou-se que a maioria dos participantes era composta de homens, idosos, com estomia recente, de raça branca, casados, com profissão de lavrador e ocupação de aposentado, escolaridade de 1 a 5 anos e faixa salarial de 1 a 2 salários mínimos. A doença precursora das estomias foi o câncer colorretal. O Serviço de Atenção à Saúde da Pessoa Ostomizada de Diamantina pode ser caracterizado como nível II, com implantação satisfatória, porém não plena. Conclusão: Espera-se que esses achados possam subsidiar diretrizes de orientação multiprofissional e de políticas públicas.

DESCRITORES: Estomaterapia; Avaliação de serviços de saúde; Autocuidado

\section{RESUMEN}

Objetivos: Caracterizar la clientela con estomía de eliminación y analizar el grado de implantación de la Política de Atención a la Salud de la Persona Ostomizada de Diamantina/MG. Método: Estudio descriptivo y transversal. La muestra estuvo compuesta por 107 personas con estomía de eliminación registrada en el periodo de octubre de 2013 a agosto de 2015. El estudio incluyó dos etapas en las cuales se caracterizó el perfil de la clientela y analizó toda la estructura del Servicio de Atención a la Salud de la Persona Ostomizada de acuerdo con cuestionarios validados. Resultados: Se constató que la mayoría de los participantes estaba compuesta por hombres, adultos mayores, con estomía reciente, de raza blanca, casados, con profesión de labrador y de ocupación jubilados, escolaridad de 1 a 5 años y franja salarial de 1 a 2 salarios mínimos. La enfermedad precursora de las estomías fue el cáncer colorrectal. El Servicio de Atención a la Salud de la Persona Ostomizada de Diamantina puede caracterizarse como nivel II, con implantación satisfactoria, pero no plena. Conclusión: Se espera que estos hallazgos puedan asistir a las directivas de orientación multiprofesional y de políticas públicas.

DESCRIPTORES: Estomaterapia; Evaluación de servicios de salud; Autocuidado

\section{INTRODUCTION}

The making of an elimination stoma occurs as a result of a surgical procedure that consists of the exteriorization of part of the digestive or urinary system through an opening in the abdominal wall ${ }^{1,2}$. This procedure is performed to maintain the excretion function of the organ and causes various changes in the physical, psychological, social and sexual health of the person who has to live with this condition ${ }^{3,4}$, besides generating the dependence of a bag adhered to the body to collect effluents, which may be urine or feces, depending on the type of stoma ${ }^{1}$.

The urinary stomas are performed in patients with diseases involving renal pelvis, ureters, bladder and urethra, with the purpose to preserve the renal function ${ }^{5}$. The intestinal stoma is indicated when some part of the intestine presents dysfunction. In this group are the ileostomy, which is in the ileum, and the colostomy, derived from the large intestine. Stomas can be characterized as a temporary or permanent deviation and are related to several causes, such as inflammatory bowel diseases, traumas and colorectal cancer ${ }^{6}$.
In order to adapt the patient to this new context, it is necessary to provide multidisciplinary care provided by doctors, nurses, psychologists, social workers and nutritionists who advise physical and psychiatric measures to coexist with the stoma from the preoperative period ${ }^{7}$.

In Brazil, there is a growing concern with this public confirmed by an effective political approach that has been guaranteeing the rights of the person with stoma, offering multidisciplinary care and dispensation of collector devices without burden to the person.

The first registry of health care for the person with stoma in the Unified Health System (UHS) occurred in 1993, with Ordinance MS/GM nº116, September 9, 1993, in which a table was established with resources to acquire the collector devices and the compulsory training.

Another high benefit was the approval of Ordinance ${ }^{\circ}$ 400, November 16, 2009, in which the National Guidelines for Attention to the Health of Ostomized People within the scope of the UHS were established, characterizing the Service of Attention to the Health of the Ostomized Person (SAHOP). This service provides integral care to the health of the person with stoma'. 
At the outpatient level, SAHOP are categorized into level I and level II. The service I provides specialized assistance of an interdisciplinary nature to people with stoma, with a minimum team composed of a doctor, nurse and social worker, aiming at their rehabilitation with emphasis on self-care, prevention of complications and supply of collector equipment. The service II, in addition to the assignments of I, performs treatment of complications and training of other network professionals, adding, in the minimum team, nutritionist and psychologist 9 .

According to the results of a survey realized in Minas Gerais in 2011, most of the SAHOP were not complying with the laws that govern its, with deficits in the physical and professional structure and in processes and results, not corresponding to the degree of implementation previously categorized in I or II, in addition to the finding that, in these services, the situational diagnoses in relation to the epidemiological data were deficient ${ }^{2}$.

In the city of Diamantina, care for the person with intestinal and urinary stoma began at the Specialized Rehabilitation Center (SRC) on October 1, 2013, and attends the demand from the five microregions formed by Diamantina, Curvelo, Guanhães, Araçuaí and Minas Novas/Turmalina/Capelinha, totaling 51 municipalities. As this service was created in 2013, it did not participate in the evaluation realized in 2011 , so it is necessary to know the profile of the clientele served in it, in addition to the quality of the service provided.

The identification of epidemiological data to characterize the clientele of a referral service to the person with stoma and the obtaining of situational data regarding the structure of the service will enable the professionals to evaluate and understand the health situation as a whole and identify failures in the program, with consequent implementation of proposals to improve the quality of patient care and rehabilitation. It can also provide managers with the conditions to decide how to deal with and solve the problems detected in the daily life of this health service.

\section{OBJECTIVES}

To characterize the clientele with elimination stoma and to analyze the degree of implementation of the Health
Care Policy of the Ostomized Person of the SAHOP of Diamantina, in the state of Minas Gerais.

\section{METHODS}

This is a descriptive and cross-sectional study developed in SAHOP Type II of a type IV SRC of Diamantina/MG. The research was developed in two stages; the first sought the characterization of the clientele with stoma attended and the second consisted of the evaluation of the service.

The SRC is a point of outpatient care specialized in rehabilitation (auditory, physical, intellectual, visual, stoma or multiple disabilities). It may consist of two (SRC II), three (SRC III) or four or more (SRC IV) rehabilitation services enabled. The SRC qualified in the physical rehabilitation modality should have the SAHOP II incorporated, with regional coverage, observing the guidelines described in Ordinance SAS/MS no 400/2009 and in the Ordinance GM/MS no 793/2012 $2^{9,10}$.

The first stage of this study comprised all people with elimination stoma diseases enrolled in the SAHOP of Diamantina/MG. In order to be part of the research, it was necessary to meet the criteria that included the existence of a record of the person with an elimination stoma registered in this service from October 2013 to August 2015. The population consisted of 107 people, 97 adults and 10 children, with $100 \%$ of these inserted in the research.

The research was developed in accordance with the norms of Resolution no 466/2012, by the National Health Council, which establishes ethical criteria for research involving human beings. The approval of the SRC of Diamantina / MG and approval of the Research Ethics Committee of the Federal University of Minas Gerais through CAAE no 49365115.0.0000.5149 were obtained. In the stage regarding the characterization of the clientele, the exemption of the Free and Informed Consent Term (FICT) was requested, since the data were collected from medical records and anonymity was maintained. At the stage where the professional answered the questionnaire on the structure of the service, the FICT was applied.

Data collection was realized in August 2015. In the study phase on patient characterization, patient identification data were collected and related to 
demographic, socioeconomic, epidemiological, clinical and behavioral variables. The data were extracted from a secondary source, collected from the records "Registration of Ostomized Person" and "Evaluation Nursing of Ostomized Person", filled in electronic system during the first appointment of the patient in the SAHOP. The records were systematized questionnaires in a check-list format that also included data on the level of understanding of the patient regarding the surgery performed and the reason for the construction of the stoma and the capacity to perform self-care after the first guidelines.

The second stage of the study consisted in evaluating the service. The data were collected based on specific instruments, validated by Moraes ${ }^{2}$, to evaluate the degree of implementation of the SAHOP. The criterion for selecting the professional responsible for completing these instruments was the one that would contain all the information pertinent to the structure and functioning of the SAHOP, excluding the researcher who was part of the professional team. Therefore, the doctor-surgeon general was selected to participate in the research.

All data relating to clientele characterization were entered in an Excel@ worksheet, transported and analyzed using the statistical package $\mathrm{R}^{*}$ (version 3.2.2).

For the analysis of the quality of the SAHOP, the chosen instrument has a score calculation algorithm also validated for this purpose ${ }^{2}$. Each answer received a value associated to the score and these, together, determined the service grade. The standardization of these scores was established in 80 points distributed between structure (30 points) and process (50 points). The structure was analyzed in two factors: physical structure (15 points) and professional resources (15 points). The process score was distributed between individual health care activities (30 points) and extended care (20 points), which correspond to the activities of the SAHOP I and II, respectively ${ }^{2}$.

Based on these scores, it can confirm the true degree of implementation of the service and its level of quality. This calculation was performed as follows: observed sum/ sum of the maximum scores multiplied by 100 . From these percentages, the classification of the SAHOP is defined, adopting the criteria: structure and process with full implementation, when the obtained score reaches percentages between $80.0 \%$ and $100.0 \%$; satisfactory implantation, from $60.0 \%$ to $79.9 \%$; implantation incipient, from $40.0 \%$ to $59.9 \%$; and not implanted, below $40.0 \%{ }^{2}$.

\section{RESULTS}

In the first stage of the study about clientele characterization, the sample consisted of 107 participants, 97 adults and 10 children, evaluated separately in order to avoid biases related to age differences. The variables related to naturalness and origin were analyzed according to the total number of patients; for demographic, socioeconomic, epidemiological, clinical and behavioral variables, adults and children were considered separately.

As for naturalness and origin, most were from the city of Diamantina. When analyzing the origin according to the Microregional Health Assisted, 59.8\% were from the Diamantina microregion, followed by $26.2 \%$ of the microregional called Minas Novas/Turmalina/ Capelinha.

About the adult patients enrolled in the program, $45.8 \%$ had a recent stoma, with 0 to 6 months of time from surgery to enrollment in the program, followed by $19.8 \%$ who had stoma between 1 and 5 years of surgery. Regarding marital status, $41.7 \%$ were married, $28.1 \%$ were widowers and $19.8 \%$ were single. The predominant profession during the working life was a farmer (37.8\%) and the occupation at the time of registration was retired (54.2\%), followed by the pensioner (20.8\%); $19.8 \%$ were receiving temporary withdrawal benefits. The schooling presented was 1 to 5 years of study (39\%) or no study (28.4\%). The individual monthly income was based on the minimum wage and $80.2 \%$ received from 1 to 2 salaries, followed by $14.6 \%$ with no fixed income.

Regarding the epidemiological variables, the majority of the patients were elderly over 60 years old (51.4\%), men $(54.2 \%)$ and white colour $(60.8 \%)$. The prevalent associated disease was systemic arterial hypertension (48.5\%) and $37.1 \%$ denied any type of prior disease. Rectum neoplasia was the predominant precursor disease of the stoma (19.6\%). When considering colorectal cancer, including rectum, colon and rectosigmoid junction involvement, this percentage reached $32.7 \%$. Another frequent cause was the megacolon caused by Chagas disease (11.2\%) (Table 1).

Regarding the clinical variables, $82.6 \%$ of the sample had no locomotion-related deficits, and the most frequent medication was antihypertensive (45.4\%). It was verified 
Table 1. Distribution of epidemiological variables $(n=107)$ referring to the characterization of the clientele with stoma in the Service of Health Care Policy of Ostomized Person in Diamantina/MG.

\begin{tabular}{|c|c|c|}
\hline Variables & $\mathrm{n}$ & $\%$ \\
\hline \multicolumn{3}{|l|}{ Age group } \\
\hline 0 to 11 & 10 & 9.3 \\
\hline 12 to 18 & 2 & 1.9 \\
\hline 19 to 59 & 40 & 37.4 \\
\hline 60 or more & 55 & 51.4 \\
\hline \multicolumn{3}{|l|}{ Gender } \\
\hline Female & 49 & 45.8 \\
\hline Male & 58 & 54.2 \\
\hline \multicolumn{3}{|l|}{ Ethnic group } \\
\hline Caucasian & 65 & 60.8 \\
\hline Indigenous & 1 & 0.9 \\
\hline Black & 13 & 12.1 \\
\hline Brownish & 28 & 26.2 \\
\hline \multicolumn{3}{|l|}{ Comorbidities $^{1}$} \\
\hline Cardiopathy & 10 & 10.3 \\
\hline Diabetes mellitus & 7 & 7.2 \\
\hline Chagas Disease & 12 & 12.4 \\
\hline Systemic arterial hypertension & 47 & 48.5 \\
\hline Hypercholesterolemia & 5 & 5.2 \\
\hline Deny* & 36 & 37.1 \\
\hline Others & 33 & 34.0 \\
\hline
\end{tabular}

Precursor disease of the estomas

\begin{tabular}{ccc} 
Megacolon of Chafas Disease & 12 & 10.2 \\
Bladder neoplam & 11 & 10.3 \\
\hline Rectosigmoid junction neoplasm & 6 & 5.6 \\
\hline Neoplasm of the cervix & 6 & 5.6 \\
\hline Colon neoplasm & 8 & 7.5 \\
\hline Neoplasm & 21 & 19.6 \\
\hline Injury of the colon & 7 & 6.5 \\
\hline Injury of the rectum & 6 & 5.6 \\
\hline Others & 30 & 28.1
\end{tabular}

Several patients had more than one comorbidity. *Denied any comorbidity.

that $40.2 \%$ of the patients were submitted to emergency laparotomy, $30.9 \%$ to the eversion in the loop and $27.8 \%$ to the hemicolectomy. Regarding the type of construction of the stoma, $56.7 \%$ were temporary and $43.3 \%$ were permanent; $20.6 \%$ were colostomies, $18.6 \%$ were colostomies to Hartman, $14.4 \%$ were terminal colostomies due to abdominoperineal amputation, and the remaining $46.4 \%$ were associated with Bricker-type stomas, ascending and transverse colostomies in a loop, loop ileostomies, among others.

The consistency of effluent in the feces at the time of admission to the service was pasty (39.2\%), formed (28.9\%), liquid (8.2\%) and semi-pasty (7.2\%); in urine, $15.5 \%$ had normal characteristics and $1.0 \%$ were concentrated.

The prevailing location of stoma in the abdomen was in the lower left quadrant, totaling $54.6 \%$ of the sample. The predominant characteristics of the stoma were regular round shape (83.5\%), diameter from 20 to $38 \mathrm{~mm}(57.0 \%)$ and protrusion level in relation to the skin from 0 to $15 \mathrm{~mm}$ (79.3\%). It was noted that $62.9 \%$ had protruding and $30.9 \%$ flat stomas, and some patients had retraction and prolapse, $4.1 \%$ and $2.1 \%$, respectively. The complications presented by $53.6 \%$ of the patients were dermatitis peristome (37.1\%) and paracolostomic hernia (17.5\%).

When evaluating the patient's understanding of the surgery performed and the reason that led to the construction of the stoma, $52.6 \%$ of the people with stoma had complete understanding, $38.1 \%$ had partial understanding and 9.3\% attended the service without some understanding of their real situation. At the end of the first consultation of the patients, $74.2 \%$ were able to practice self-care, $15.5 \%$ reported partial dependence and $10.3 \%$ presented total dependence.

Regarding children (10), the age varied from 0 to 6 months for six children, 7 to 11 months for two children, a child between 1 and 5 years and one between 6 and 10 years. Only one had impairment of mobility. The most common medications were anti-anemic (25\%) and vitamin supplementation (25\%). Regarding the characteristics of the stoma and effluent, six children presented stoma for less than six months. The most common surgical procedure, as well as in adults, was emergency laparotomy with stoma construction like descending colostomy in loop (30\%). Ileostomy in the loop and vesicostomy represented both $20 \%$ of the sample. The remaining $30 \%$ added stomas like double cavity attached colostomy, terminal and transverse in loop. The majority had semi-pasty effluent. All the children had stoma with the possibility of reversion in the future and five had stoma in the lower left quadrant of the abdomen. Most of the stomas were regular and round (90\%), with a diameter ranging from 0 to $19 \mathrm{~mm}$ (44.4\%) and protrusion in relation to the skin (100\%). The most 
common complication was dermatitis (50\%). One child had partial capacity for self-care, the others totally dependent on adults. As to the analysis of the understanding about the surgical act and the reason of the stoma construction, this was not observed in any child.

The second stage of the study consisted in the evaluation of the service through the Matrix of Analysis and Judgment of the SAHOP. The scores obtained in structure and human resources were 26 points (total of 30 points), highlighting the lack of a bathroom adapted to the person with stoma, the presence of a trained nurse to the detriment of the stomatherapist and the absence of an administrative agent. In the process dimension, related to the assignments and activities of the professionals, the score obtained was 31 points (total of 50 points), with subtraction in the items related to the organization of care, registration and updating of data, guidance and training of other network professionals.

Collector and adjuvant devices were dispensed daily and those of greater use among patients were one and two-part drainage and opaque colostomy bags, followed by urinary devices and closed bowel devices. The aspect evaluated as a priority when indicating collector devices was the confidence in the equipment.

In relation to the calculation of the true Degree of Service Deployment and its level of quality: observed sum $(57$ points)/sum of the maximal scores $(80) \times 100$, obtaining $71.25 \%$ and reaching the parameter of implantation satisfactory level of classification.

\section{DISCUSSION}

It is extremely important that the multidisciplinary team knows the general and individual characteristics of the population served in order to act satisfactorily in the clinical approaches. It is also important to evaluate the Health Services to carry out a reorganization of the assistance with the objective of achieving the principles of universality, equity and integrality ${ }^{5}$.

When analyzing the origin of the patients enrolled in the SAHOP of Diamantina/MG in relation to the number of inhabitants of the microregions served, it was found that the Diamantina microregion is not the largest in population, but it contains the largest number of patients. The regions referenced to this service add up to a considerable territorial area, which led us to question the patients' reference form and the existence of people with stomas without adequate care. The location of patients' residence often imposes barriers to the use of health services. A study realized in Porto Alegre/RS identified that access is influenced by the distance between the dwelling and the service, as well as the form and the time of displacement ${ }^{11}$.

It was verified in this research that the majority of the patients enrolled in the SAHPO of Diamantina had a recent stoma, showing an evolution, since these are being referenced to the rehabilitation service more quickly, unlike studies that demonstrate a still incipient disclosure of the rehabilitation services next to hospitals ${ }^{6,12}$.

Most registered patients are married. This fact is important for eliciting reflections on the proper way to approach the person with the stoma about sexuality. The sexual life of these people is subject to restrictions caused by mutilations of nerves related to the functioning of the sexual organs and also by psychoemotional reasons caused by feelings of shame and sexual disinterest, facts that must be treated by the team ${ }^{13}$.

The predominant profession of farmer during the active phase of the patients resembles the study realized in a public hospital in Teresina/PI ${ }^{14}$. The predominant occupation of retirees, followed by pensioners and retirees, is similar to studies on the characterization of clients with stomas that emphasizes the difficulty of reinsertion in the work of this group of patients ${ }^{1,6,15-19}$.

People with stoma have difficulty getting back to work. Faced with the change in body image, they have feelings of fear, loneliness and impotence. Generally, those who have an employment relationship prefer to retire and the unemployed have difficulty finding work. They often avoid public places and social interaction ${ }^{20}$. During rehabilitation, it is necessary, through social support, to watch for the stimulus to return to labor practices.

In relation to schooling, the largest proportion of incomplete Elementary school students, followed by illiterates with low income, is similar to several studies ${ }^{5,6,14}$. ${ }^{16-18}$. Such data may be related to the fact that these health programs are offered by the Government through the UHS and reach, for the most part, users of low socioeconomic status. This issue is also inherent in emphasizing the importance of the free distribution of the equipment and adjuvants necessary for a good quality of life of the patient through the $\mathrm{SAHOP}^{5,6}$. 
The highest proportion of the elderly population present in the study is compatible with others on people with stoma ${ }^{5,15,17,19}$. With the increase in life expectancy, age is considered a risk factor for morbidity and mortality related to chronic non-communicable diseases, especially cancer21. The team, when dealing with the care of the elderly with stoma, must take into account that functional and cognitive changes occur and should be taken into account in the management of the stoma ${ }^{4}$.

Colorectal cancer was identified as the main cause of stoma, with the predominance of men. These data differ from a study that relates the greater proportion of men to situations in which the main cause is traumatic by violence ${ }^{14}$. The high index of stomas caused by megacolon of Chagas, which occupies the second place in the manufacture of stomas in the sample of this research, is justified by the fact that the region studied is inserted in an endemic area of this disease, and the primary attention should be given to greater investment preventive aspects.

It should be emphasized that the gender of the person with stoma can influence the adaptation, and the professional should pay attention to this issue. Women tend to require less time for rehabilitation, although they show degrees of depression and fear in the preoperative period. Men, especially those who develop sexual impotence, take a longer time to resume their quality of life and present greater difficulties for self-care ${ }^{22,23}$.

Skin color was also verified in this study as well as in a study about the characterization of people with stomies in the municipality of Ponte Nova/MG, where both individuals are predominantly white. It is noteworthy that there are few studies in the scientific literature in which patients with stoma ${ }^{5}$.

A socio-epidemiological data not evaluated in this research, because this information is not included in the evaluation form of the person with stomas of the State Department of Health (SDH), is related to religiosity. The investigation of the existence of spirituality in patients with stomas, as in any other patient, is necessary, since there are scientific investigations proving that people with spiritual well-being and religious belief can have their health affected positively, since in Instead of limiting themselves to the reductionist explanations of medicine, they reach feelings of confidence, surpassing and relief that can help in overcoming this phase of difficulties ${ }^{23}$.
This research, like most studies analyzed, points to colorectal cancer as the main predictor of stomas ${ }^{1,5,6,15-17,19}$. The colostomy is performed when the tumor compresses the intestinal loop, which causes obstruction, and is also used when much of the bowel is removed. The incidence increases with age and is more frequent in people who eat carcinogenic chemicals with excessive caloric intake and lack of antioxidant micronutrients, such as carotenoids, selenium and vitamins $\mathrm{A}, \mathrm{C}$ and $\mathrm{E}$, in addition to having a family history of cancer intestinal, polyp or inflammatory disease ${ }^{16}$. A continuous investment in the dissemination and implementation of preventive measures, including the carrying out of examinations for the early diagnosis of the disease, is essential, in order to avoid and reduce the need for stomas 5 .

Comorbidities prior to the accomplishment of the stoma were evaluated, with hypertension being identified with a higher index, as well as in a study that characterized clinical and epidemiological aspects of people with an omen in a city of Minas Gerais ${ }^{15}$. The use of antihypertensive was prevalent in the studied population, a fact that is related to the older age group and the consequent increase of chronic diseases. Most patients had no mobility restrictions. A study was identified that addressed medications and movement difficulties in relation to people with stomas, and most also did not present difficulties ${ }^{18}$.

Regarding the surgical procedure, it was observed that most of the patients were submitted an emergency laparotomy, followed by stoma preparation, a fact that may influence the quality of life of these patients, who were not prepared for such procedure. The types of stoma construction prevalent in this research were: descending colostomy in the loop, terminal colostomy in the Hartman, and definitive terminal colostomy due to abdominoperineal amputation, which are usually performed as a complement to another surgical procedure ${ }^{14}$. Terminal colostomies, for example, result from abdominoperineal amputation of the rectum, common in cases of advanced colorectal cancer, which makes it impossible to reconstruct intestinal transit, or after Hartmann's operation (sigmoidectomy or rectosigmoidectomy with burial of the rectum stump $)^{24}$.

A study realized in a public hospital in Teresina/PI concluded that there are divergences in the results related to the permanence of the stomas, due to the fact that this permanence is directly related to the causes that motivated it. While the definitive ones are more frequently associated 
with colorectal and urogenital cancer, the temporary ones may be related to traumas. In the Teresina/PI study, the intestinal stoma time ranged from $68.42 \%$ (temporary) to $31.58 \%$ (permanent), with obstructions and trauma being its main causes ${ }^{14}$. In the present research, the temporary colostomies have stood out even though the traumas are not the main cause of the manufacture of the stomas.

When analyzing the characteristics of the effluent eliminated by the stoma, there was a predominance of those that presented pasty or formed feces at the time of admission to the service, a fact that is related to the location of the stoma, mostly in the left colon. This type of effluent favors the rehabilitation since it avoids that possible infiltrations damages the protective barrier of the device ${ }^{15}$.

It was found that the predominant shape of the stomas was of the regular round type, with the diameters being more common in the range of 20 to $38 \mathrm{~mm}$, and that most of these were protruding in relation to the skin. A study realized in a Care of the Ostomized Person of Ponte Nova/ $\mathrm{MG}^{5}$ reported that the patients had a stomatal diameter of 22 to $40 \mathrm{~mm}$ and that in $75.0 \%$ there was no protrusion, with the stoma flat. When the stoma is protruding, this condition benefits the quality of life and comfort of the patient, since the collector system is easily adapted, its durability is greater and this prevents infiltration and effluent leakage ${ }^{15}$. It is known that the diameter interferes with the cut and adaptation of the collector device ${ }^{5}$, but it has not been found in the literature on the ideal size of the stoma.

Among the complications identified in this study, peristaltic dermatitis was the most common, a fact that corroborates studies that did the same analysis ${ }^{5,14,19}$. Dermatitis usually occurs due to improper use of collector equipment, more precisely by excessive cutting of the orifice from the protective barrier to the stoma, leaving the skin exposed to effluent action or by improper indication of the equipment. Collector equipment and adjuvants on the market should be presented in the smallest detail to patients with stoma, and a continuous reevaluation is necessary as to the correct use of these as, over time, they may require modifications, hence the importance of continuous maintenance of patients in the rehabilitation services while they have the stoma ${ }^{5}$. It should be noted that in the Diamantina SAHOP, patients are reevaluated within a maximum period of four months and there is a high resolving rate of dermatitis.
The large number of patients who reported some knowledge about the surgical procedure performed and presented aptitude for self-care identified in this study may be related to the low index of diseases that cause cognitive deficits and mobility restrictions, the patients being mostly healthy and guidance provided. In practice, it is common for patients with cognitive impairment not to self-care. There is also greater resistance among men, because they prefer to accept the care of their relatives, a concept detected in another study ${ }^{22}$.

The fact that part of the patients attend the Rehabilitation Service already oriented about the surgical procedure performed and the reason for the construction of the stoma helps in the adaptation process and demonstrates that the hospital institutions have improved their practices of guidelines. A similar study concluded that patients who were advised about health status, as well as about self-care techniques, had greater acceptance and adaptation to the stoma ${ }^{25}$.

The children of this research had as main cause of the Hirschsprung syndrome or congenital megacolon and other causes related to congenital malformations. This data is corroborated by a study realized in Distrito Federal with 50 children with stoma, $80 \%$ of whom were due to congenital malformations, $48 \%$ of whom had a diagnosis of congenital megacolon, followed by $14 \%$ of imperforate anus ${ }^{26}$.

Six children were enrolled in the service shortly after discharge; a child had had stoma for seven years, but used diapers, because the family did not know the collector devices and happened to be inserted in the program.

Publications regarding children with stomas are scarce, especially regarding the clinical and epidemiological profile. This fact was confirmed in two review studies published in 2015. They both addressed the child with the stoma, but did not include such data. The first study ${ }^{27}$ was composed of five qualitative articles, published in the period from 2008 to 2013, which addressed issues related to the difficulties faced by the relatives of children with stomas and to the failure of the health professionals. The second review study ${ }^{28}$ counted on five articles in the sample, published between 2010 and 2014. The approach was about caring for the child with stoma, quality of life and relationship with the family. The research showed the necessity to empower the family in the daily care of their children with intestinal stomas.

When analyzing the results regarding the evaluation of the service, it was verified that, according to Ordinance $n^{\circ} 400$ 
of November 16, 2009, the SAHOP of Diamantina/MG is justified to the degree of implantation level II. The result found shows a satisfactory, but not full, implementation, that is, the service presented the parameters for this degree of implantation, but it needed adjustments to obtain better results. The number of professionals was sufficient for the service to be classified at that level, possessing, in addition to the minimum professionals required, an additional doctor and a nursing technician. Of the practicing doctors, one was a urologist, for follow-up of urinary stomas, and the other was a general surgeon, for the intestinal stomies. The nursing technician assisted in dispensing the devices. Other characteristics to obtain the degree of implantation level II are the treatment of complications related to the stomas and the qualification of professionals of the network, attributions present in the service.

When analyzing the individual consultations, it was noticed that these were priorities in this program, so much that they were realized in the maximum period of four months, established by Ordinance no 400 , of November 16 , 2009. The physical structure and the material resources were adequate, but the private bathroom was non-existent and adapted to patients with an ovaries, which is a suggestion in order to better accommodate the users.

The duties related to the organization of the demand for care, to the registration of the patients and to the updating of the data, that is, the bureaucratic assignments, which could be performed by an administrative agent, were performed by the nurse. Training-related activities, which could be performed by all other program professionals, were also assigned to nurses. These characteristics related to the scores values of the Analysis and Judgment Matrix were the ones that subtracted the score from the program. The activities related to individual, group and family care had good scores, which suggests that this service not only distributes collector devices to the population, but also promotes rehabilitation.

The administrative agent is not a professional required by law, but, according to this study, would be of great value for the full implementation of the program, since it could carry out administrative and bureaucratic activities, which would allow nurses to work longer in care, participating in group activities and training for network professionals ${ }^{2}$. The professionals of the care network (primary and tertiary care of the microregions assisted by the SAHOP) who receive adequate training can act satisfactorily in the continuity of the rehabilitation of the patients that are further from the SAHOP, as well as in the pre-surgical orientations. The group activities are significant, since the patient who communicates with other professionals besides the nurse and with other patients and relatives who coexist with the same condition strengthens and is encouraged to face the difficulties of the day to day, returning to the environment of work and resume leisure and conjugal life, finally resuming his life.

The fact that this study was realized in a single context may predispose to the limitation to the generalization of the results of this research, since the studied group is concentrated in a certain region.

\section{CONCLUSION}

The SAHOP of Diamantina registered 107 patients from October 2013 to August 2015, 97 adults and 10 children. It was realized the characterization of this clientele referring to the demographic and socioeconomic variables, epidemiological, clinical and behavioral.

The SAHOP of Diamantina can be characterized as level II of attention to the health of the patient with stomas and totals a score of $71.25 \%$ referring to the Matrix of Analysis and Judgment, corresponding to a satisfactory, but not full implantation. Group activities and training may obtain higher scores if the nurse engages in these activities to the detriment of bureaucratic activities, which can be performed by an administrative agent, which would further improve care for patients with stoma in this service.

It is hoped that the data identified may support the managers, both at the state and municipal levels, in the creation of strategies to guarantee the rehabilitation of patients with stomas, as well as improvement in the levels of screening and early diagnosis of precursor diseases of the stomas. With regard to clinical care, an improvement in the planning of specialized assistance to this clientele is expected, with adjustments in rehabilitation strategies in order to guarantee full assistance.

\section{AUTHOR'S CONTRIBUTION}

Conceptualization, Freitas JPC and Borges EL; Methodology, Bodevan EC; Investigation, Freitas JPC and Borges EL; Writing - Original draft, Freitas JPC; Writing - Revision \& Edition, Freitas JPC and Borges EL; Supervision, Borges EL. 
1. Mota MS, Gomes GC, Petuco VM, Heck RM, Barros EJL, Gomes VL. Facilitadores do processo de transição para - autocuidado da pessoa com estoma: subsídios para enfermagem. Rev Esc Enferm USP. 2015;49(1):82-8. doi: 10.1590/s0080-623420150000100011.

2. Moraes JT, Amaral CFS, Borges EL, Ribeiro MS, Guimarães EAA. Validação de um instrumento para avaliação de serviços de atenção à saúde da pessoa estomizada. Rev Latino-Am Enferm. 2016;24. doi: 10.1590/1518-8345.0748.2825.

3. Altschuler A, Ramirez M, Grant M, Wendel C, Hornbrook MC, Herrinton L, et al. The influence of husbands' or male partners' support on women's psychosocial adjustment to having an ostomy resulting from colorectal cancer. J Wound Ostomy Continence Nurs. 2009;36(3):299-305. doi: 10.1097/ won.0b013e3181a1a1dc.

4. Sun V, Grant M, McMullen CK, Altschuler A, Mohler MJ, Hornbrook MC, et al. Surviving colorectal cancer: long-term, persistent ostomy-specific concerns and adaptations. J Wound Ostomy Continence Nurs. 2013;40(1):61-72. doi: 10.1097/won.0b013e3182750143.

5. Fernandes RM, Miguir ELB, Donoso TV. Perfil da clientela estomizada residente no município de Ponte Nova, MG. Rev Bras Coloproct [Internet]. 2011;30(4):385-92. doi: 10.1590/ s0101-98802010000400001.

6. Lenza NFB, Sonobe HM, Zago MMF, Buetto LS. Características socioculturais e clínicas de estomizados intestinais e de familiares em um Programa de Ostomizados. Rev Eletr Enf. 2013;15(3):755-62. doi: 10.5216/ree.v15i3.17594.

7. Rocha JJR. Estomias intestinais (ileostomias e colostomias) e anastomoses intestinais. Med. Ribeirão Preto, São Paulo. 2011;(44):51-6. doi: 10.11606/issn.2176-7262. v44i1 p51-56.

8. Brasil. Ministério da Saúde. Secretaria de Atenção à Saúde. Inclui no Sistema de Informações Ambulatoriais do Sistema Único de Saúde - SIA/SUS a concessão dos equipamentos de órteses, próteses e bolsas de colostomias. Portaria MS/ SAS n. 116, 9 setembro 1993. BVS MS: Biblioteca Virtual em Saúde. Brasília; 1993.

9. Brasil. Ministério da Saúde. Secretaria de Atenção à Saúde. Estabelece Diretrizes Nacionais para a Atenção à Saúde das Pessoas Ostomizadas no âmbito do Sistema Único de Saúde - SUS. Portaria MS/SAS n. 400, 16 novembro 2009. BVS MS: Biblioteca Virtual em Saúde. Brasília; 2009.

10. Brasil. Ministério da Saúde. Gabinete do Ministro. Institui a Rede de Cuidados à Pessoa com Deficiência no Âmbito do Sistema Único de Saúde. Portaria MS/GM n. 793, 24 abril 2012. BVS MS: Biblioteca Virtual em Saúde. Brasília; 2012.

11. Dall'Agnol CM, Lima MADS, Ramos DD. Fatores que interferem no acesso de usuários a um ambulatório básico de saúde. Rev Eletr Enf. 2009;11(3):674-80.

12. Silva NG, Gama FA. Dutra RA. Percepção de pacientes com estomia sobre mitos e medos relacionados a esta condição. ESTIMA, Braz J Enterostomal Ther. 2008;6(1):22-6.

13. Silva AL, Shimizu HE. O significado da mudança no modo de vida da pessoa com estomia intestinal definitiva. Rev Latino Am Enfermagem. 2006;14(4):483-90. doi: 10.1590/s010411692006000400003.
14. Luz MHBA, Andrade DS, Amaral HO, Bezerra SMG, Benício CDAV, Leal ACA. Caracterização dos pacientes submetidos a estomas intestinais em um hospital público de TeresinaPI. Texto Contexto Enferm. 2009;18(1):140-6. doi: 10.1590/ s0104-07072009000100017.

15. Barbosa MH, Poggetto MTD, Barichello E, Cunha DF, Silva $\mathrm{R}$, Alves PIC, et al. Aspectos clínicos e epidemiológicos de estomizados intestinais de um município de Minas Gerais. REAS. 2014;3(1):64-73.

16. Moraes JT. Sousa LA. Carmo WJ. Análise do autocuidado das pessoas estomizadas em um município do centro-oeste de Minas Gerais. RECOM. 2012;2(3):337-46.

17. Melotti LF, Bueno IM, Silveira GV, Silva MEN, Fedosse E. Characterization of patients with ostomy treated at a public municipal and regional reference center. J Coloproct. 2013;33(2):70-4. doi: 10.1016/j.jcol.2013.04.003.

18. Souza MA, Santos BC, Soares GO, Santana O. Perfil clínico-epidemiológico de los pacientes atendidos y censados en el Centro Paraibano de Ostomizados. Gerokomos. 2010;21(4):183-90. doi: 10.4321/s1134$928 \times 2010000400007$.

19. Salomé GM, Carvalho MRF, Junior MRM, Mendes B. Profile of ostomy patients residing in Pouso Alegre city. J Coloproct. 2015;35(2):106-12. doi: 10.1016/j.jcol.2015.02.002.

20. Silva AL, Shimizu HE. A relevância da Rede de Apoio ao estomizado. Rev Bras Enferm. 2007;60(3):307-11. doi: 10.1590/s0034-71672007000300011.

21. Brasil. Ministério da Saúde. Instituto Nacional de Câncer José Alencar Gomes da Silva. Coordenação Geral de Ações Estratégicas. Coordenação de Prevenção e Vigilância. Estimativa 2012: incidência de câncer no Brasil. Rio de Janeiro: Inca, 2011.

22. Macedo MS, Nogueira LT, Luz MHBA. Perfil dos estomizados atendidos em hospital de referência em Teresina. ESTIMA, Braz J Enterostomal Ther. 2005;3(4):25-8.

23. Barbutti RCS, Silva MCP, Abreu MAL. Ostomia, uma difícil adaptação. Rev SBPH. Rio de Janeiro. 2008;11(2).

24. Silva J, Sonobe HM, Buetto LS, Santos MG, Lima MS, Sasaki VDM. Estratégias de ensino para o autocuidado de estomizados intestinais. REME. 2014;15(1):166-73. doi: 10.15253/2175-6783.2014000100021.

25. Nascimento CMS, Trindade GLB, Luz MHBA, Santiago RF. Vivência do paciente estomizado: uma contribuição para a assistência de enfermagem. Texto Contexto Enferm. 2011;20(3):557-64. doi: 10.1590/s010407072011000300018.

26. Monteiro SNC, Kamada I, Silva AL, Souza TCR. Perfil de crianças e adolescentes estomizados atendidos de um hospital público do Distrito Federal. ESTIMA, Braz J Enterostomal Ther. 2014;12(3):23-32.

27. Rosado SR, Dázio EMR, Siepierski CT, Filipini CB, Fava SMCL. O cuidado de enfermagem e as lacunas na assistência à criança com estomia: uma revisão integrativa. ESTIMA, Braz J Enterostomal Ther. 2015;13(2):83-7. doi: 10.5327/z18063144201500020008.

28. Melo MC, Kamada I. O papel da família no cuidado à criança com estoma intestinal: uma revisão narrativa. ESTIMA, Braz J Enterostomal Ther. 2015;13(3):43-9. 